\title{
The relative importance of households as a source of variation in child malnutrition: a multilevel analysis in India
}

\author{
Anoop Jain ${ }^{1}$, Justin Rodgers ${ }^{2}$, Rockli Kim ${ }^{3,4}$ and S. V. Subramanian ${ }^{5,6^{*}}$
}

\begin{abstract}
Background: Child malnutrition remains a major public health issue in India. Along with myriad upstream and social determinants of these adverse outcomes, recent studies have highlighted regional differences in mean child malnutrition rates. This research helps policy makers look between urban and rural communities and states to take a population-level approach to addressing the root causes of child malnutrition. However, one gap in this between-population approach has been the omission of households as a unit of analysis. Households could represent important sources of variation in child malnutrition within communities, districts, and states.
\end{abstract}

Methods: Using the fourth round of India's National Family Health Survey from 2015 to 2016, we analyzed four and five-level multilevel models to estimate the proportion of variation in child malnutrition attributable to states, districts, communities, households, and children.

Results: Overall, we found that of the four levels that children were nested in (households, communities, districts, and states), the greatest proportion of variation in child height-for-age $Z$ score, weight-for-age $Z$ score, weight-forheight Z score, hemoglobin, birthweight, stunting, underweight, wasting, anemia, and low birthweight was attributable to households. Furthermore, we found that when the household level is omitted from models, the variance estimates for communities and children are overestimated.

Conclusions: These findings highlight the importance of households as an important source of clustering and variation in child malnutrition outcomes. As such, policies and interventions should address household-level social determinants, such as asset and social deprivations, in order to prevent poor child growth outcomes among the most vulnerable households in India.

Keywords: Social determinants, Child malnutrition, India, Multilevel modeling, Population health, Omitted level, Households

\section{Background}

Child malnutrition remains a major public health issue in India. Often indicated by measures of child anthropometry and low hemoglobin levels, over $30 \%$ of the world's stunted children (i.e. children with $<-2 \mathrm{SD}$

*Correspondence: svsubram@hsph.harvard.edu

${ }^{6}$ Department of Social and Behavioral Sciences, Harvard T.H. Chan School of Public Health, Boston, MA 02115, USA

Full list of author information is available at the end of the article height-for-age $\mathrm{Z}$ score) lived in India in 2017 [1]. Furthermore, the prevalence of child wasting $(<-2$ SD weight-for-height $\mathrm{Z}$ score), underweight $(<-2 \mathrm{SD}$ weight-for-age $Z$ score), anemia $(<11.0 \mathrm{~g} /$ deciliter $)$, and low birthweight $(<2500 \mathrm{~g})$ was $15.7,32.7,59.7$, and $21.4 \%$, respectively $[1,2]$. In addition to being associated with an increased risk of infectious disease [3], child malnutrition is linked with impaired cognitive development that can lead to poor long-term educational and economic outcomes [4]. Furthermore, mild to moderate child 
malnutrition is associated with increased child mortality [2].

Social determinants such as household socioeconomic status, intergenerational poverty, and inadequate environmental conditions are all associated with child malnutrition [5-7]. Additionally, some studies highlight regional differences in mean child malnutrition rates. For example, districts with high rates of stunting are clustered in north and central India [8]. Other studies have shown that states such as Tamil Nadu are high performing in terms of child malnutrition outcomes, while other states, such as Bihar, Uttar Pradesh, Odisha, Madhya Pradesh, and Gujarat perform quite poorly [9]. Furthermore, multilevel analyses reveal that variations in malnutrition are most attributable to states and urban and rural communities as opposed to districts $[10,11]$. Corruption, variations in health policy and service delivery, and differences in health care spending are some of the reasons associated with disparate child malnutrition outcomes across states and communities in India [11-13].

However, one gap in these multilevel analyses and population approaches has been the omission of households as a unit of analysis. This omission may stem in part from the assumption that within-population distributions remain constant over time and across populations [14, 15]. As a result, the environments, such as households, that people are embedded in within communities, districts, or states are often disregarded. However, a strictly population-level approach does not account for heterogeneity at lower levels. This is demonstrated by the fact that over $93 \%$ of the variation in child height-for-age $\mathrm{Z}$ score (HAZ) in India was attributable to between-individual variations [11]. Similarly, another study showed that $80-85 \%$ of the variation in child hemoglobin and anthropometry in India was due to within-population differences [14]. Households are important sites of etiologic action given previously established relationships between housing characteristics, conditions, and amenities, and health [15]. As such, households could represent an important unit of investigation in multilevel analyses within communities, districts, and states.

Given this background, the purpose of this paper is to examine the proportion of variation in child stunting, wasting, underweight, anemia, and low birthweight attributable to the household level relative to commonly analyzed levels such as communities, districts, and states. We conducted this study using data from India's most recent National Family Health Survey (NFHS), and to our knowledge, no other papers using this dataset have included households as a unit of analysis. This research is significant given that India's National Nutrition Strategy (NNS) seeks to dramatically reduce the burden of child malnutrition in the coming years [16]. Achieving this goal will require an approach that targets at-risk individuals and households given how much of the variation in child malnutrition is attributable to lower levels [17-20] in addition to a population-level strategy to reduce average rates of child malnutrition across states in India [11, 21]. Therefore, this research is important as it builds on prior studies by examining households, a lower level of inferential targeting, as a possible source of variation in child malnutrition. Understanding the role households play could help policy makers intervene both between and within populations in order to improve child malnutrition throughout India.

\section{Methods}

\section{The National Family Health Survey 2015-2016}

We used the fourth round of the NFHS from 2015 to 2016 to conduct this study. Households were defined as a group of individuals who normally live together and take their meals from a common kitchen. Overall, this survey used a stratified two-stage sampling frame (states, and urban/rural areas within states) to select households and participants [22]. More specifically, households were selected from primary sampling units, defined as groups of adjacent households, which were villages in rural areas and census enumeration blocks in urban areas. We collectively refer to these village and census enumeration blocks as communities in this paper. As such, this dataset contains data from each of India's 36 states/union territories, all 640 districts, 28,522 out of over 650,000 communities, 601,509 households, and 699,686 women between the ages of 15-49. For the purposes of this paper, the survey included data on a total of 259,627 children from 180,227 households.

\section{Variables and sample sizes}

The outcomes included in our analysis were child heightfor-age $\mathrm{Z}$ score (HAZ), weight-for-height $\mathrm{Z}$ score (WHZ), weight-for-age $Z$ score (WAZ), standardized hemoglobin measures (HB), and birthweight (measured in grams). We also included stunting ( $<-2$ SD HAZ), wasting $(<-2$ SD WHZ), underweight $(<-2$ SD WAZ), anemia $(<11.0 \mathrm{~g} /$ $\mathrm{dL})$, and low birthweight $(<2500 \mathrm{~g})$. The dataset had complete HAZ, WAZ, and WHZ data for 225,002 children from 164,664 households. The dataset had complete HB data for 209,496 children from 157,746 households, and birthweight data for 184,852 children from 140,572 households. Sample sizes are fully described in Fig. 1 below. The number of states/union territories [23] and districts (640) stayed the same in all the analyses hence they are not reported in the figure.

Covariates included 19 risk factors known to be associated with child malnutrition [7, 24, 25]. We included three different nutrition variables, early breastfeeding 


\begin{tabular}{|c|c|c|}
\hline & $\begin{array}{c}259,627 \text { children belonging to } \\
190,627 \text { mothers from } 180,277 \\
\text { households in full sample }\end{array}$ & \\
\hline $\begin{array}{c}225,002 \text { children from } 164,664 \\
\text { households in } 28,164 \\
\text { communities with complete } \\
\text { HAZ, WHZ, WAZ, stunting, } \\
\text { wasting, \& underweight data }\end{array}$ & $\begin{array}{c}209,496 \text { children from } 157,746 \\
\text { households in } 28,088 \\
\text { communities with complete } \\
\text { hemoglobin/anemia data }\end{array}$ & $\begin{array}{c}184,852 \text { children from } 140,572 \\
\text { households in } 27,888 \\
\text { communities with complete } \\
\text { birthweight data }\end{array}$ \\
\hline$\nabla$ & $\nabla$ & $\nabla$ \\
\hline $\begin{array}{c}204,979 \text { children from } 150,279 \\
\text { households in } 27,980 \\
\text { communities in fully adjusted } \\
\text { primary models }\end{array}$ & $\begin{array}{c}190,227 \text { children from } 143,604 \\
\text { households in } 27,878 \\
\text { communities in fully adjusted } \\
\text { primary models }\end{array}$ & $\begin{array}{c}167,838 \text { children from } 127,726 \\
\text { households in } 27,619 \\
\text { communities in fully adjusted } \\
\text { primary models }\end{array}$ \\
\hline$\nabla$ & $\nabla$ & $\nabla$ \\
\hline $\begin{array}{c}118,073 \text { children from } 66,320 \\
\text { households in } 23,425 \\
\text { communities in fully adjusted } \\
\text { secondary models }\end{array}$ & $\begin{array}{c}109,882 \text { children from } 65,404 \\
\text { households in } 23,277 \\
\text { communities in fully adjusted } \\
\text { secondary models }\end{array}$ & $\begin{array}{c}91,662 \text { children from } 53,854 \\
\text { households in } 22,414 \\
\text { communities in fully adjusted } \\
\text { secondary models }\end{array}$ \\
\hline
\end{tabular}

initiation, vitamin A supplementation (only asked in reference to children between 6 and 59 months), and the use of iodized salt. Each of these three variables was dichotomized yes/no. We included four environmental variables, household access to improved sanitation, household use of clean cooking fuel, safe child stool disposal, and household access to improved drinking water. These variables were also dichotomized yes/no. A total of six health coverage variables were included. These were whether the child experienced an infectious disease in the past two weeks, complete child vaccinations, presence of skilled birth attendant at birth, provision of oral rehydration therapy after diarrhea, care seeking for pneumonia, and whether family planning needs were met. All of these variables were dichotomized yes/no. Household wealth, mother's level of education, and child's birth order were included as socioeconomic risk factors. Households were dichotomized by either being in the poorest wealth quintile, or in all other quintiles. Mother's education was dichotomized based on whether the mother had received no education or at least primary education. We dichotomized birth order as before or after the 6th birth. Finally, we included three maternal characteristic risk factors which were mother's age at marriage, maternal height, and maternal body mass index (BMI). Age at marriage was dichotomized as above or below 18. Mother's height was dichotomized as above and below $145 \mathrm{~cm}$, and mother's BMI was dichotomized as above and below $18.5 \mathrm{~kg} / \mathrm{m}^{2}$.

After performing listwise deletion for all missing observations for the above covariates, our fully adjusted sample sizes were 204,979 children with HAZ, WAZ, and WHZ outcome data, 190,227 children with HB outcome data, and 167,838 children with birthweight outcome data.

\section{Statistical analysis}

Our statistical analysis consisted of a series of fourand five- level models in order to compare the addition of households as a level of analysis. Additionally, each set of models included an 'unadjusted' and 'adjusted' model. The unadjusted models contained only child age (in months) and sex, while the fully adjusted 
models contained all 19 risk factors outlined above. Further, our analysis was composed of primary and secondary analyses. The primary analysis included the full sample of households, with varying numbers of children per household, whereas the secondary analysis focused on a restricted subsample composed of only those households with more than one child. This approach was taken in order to examine whether household variance estimates were attenuated by between-child estimates in households with more than one child.

\section{Continuous outcomes}

We used multilevel modeling to decompose the proportion of variation in our continuous outcomes HAZ, WHZ, WAZ, HB, and birthweight - attributable to children at level one, nested in urban/rural communities at level two, districts at level three, and states at level four. Multilevel modeling is a statistical methodology commonly used in the field of public health to elucidate the effects of both compositional and contextual factors on health [26-28]. For this four-level model, we estimated equation (1), which took the basic form $Y_{i j k l}=\beta_{0}+\beta_{1} X_{i j k l}+\left(e_{0 i j k l}+u_{0 j k l}+v_{0 k l}+f_{0 l}\right)$ where $Y_{i j k l}$ is one of the outcomes for child $i$ nested in community $j$, district $k$, and state $l$. In this model, $X_{i j k l}$ is a vector of covariates, and the random effects $e_{0 i j k l}, u_{0 j k l}$, $v_{0 k l}$, and $f_{0 l}$ are the residual differentials for children, communities, districts, and states, respectively. We then included households such that we decomposed the proportion of variation in the same continuous outcomes attributable to children at level one, nested in households at level two, communities at level three, districts at level four, and states at level five. For this five-level model, we estimated equation (2), which took the basic form $Y_{i j k l m}=\beta_{0}+\beta_{1} X_{i j k l}+\left(e_{0 i y j k l}+h_{0 y j k l}\right.$ $\left.+u_{0 j k l}+v_{0 k l}+f_{0 l}\right)$ where $Y_{i y j k l}$ is one of the outcomes for child $i$ nested in household $y$, community $j$, district $k$, and state $l$. In this model, $X_{i y j k l}$ is a vector of covariates, and the random effects $e_{0 i y j k l}, h_{0 y j k l}, u_{0 j k l}, v_{0 k l}$, and $f_{0 l}$ are the residual differentials for children, households, communities, districts, and states, respectively. In both the four-level and five-level models, the residual differentials for children, households, communities, districts, and states are assumed to be normally distributed with a mean of 0 and a variance of $\sigma_{e 0}^{2}, \sigma_{h 0}^{2}$, $\sigma_{u 0}^{2}, \sigma_{v 0}^{2}$, and $\sigma_{f 0}^{2}$, respectively. The variances in the four and five-level models are the parameters of interest and signify the between-child $\left(\sigma_{e 0}^{2}\right)$, between-household $\left(\sigma_{h 0}^{2}\right)$, between-community $\left(\sigma_{u 0}^{2}\right)$, between-district $\left(\sigma_{v 0}^{2}\right)$, and between-state $\left(\sigma_{f 0}^{2}\right)$ variations in child $i$ experiencing the outcome. Finally, we repeated the five-level analysis for a subsample of households with more than one child.

\section{Binary outcomes}

For the binary outcomes stunting, wasting, underweight, anemia, and low birthweight, we estimated four level models for the probability of a child $i$, in community $j$, in district $k$, in state $l$ experiencing the outcome $Y_{i j k l}=1$ as equation (3) $\operatorname{logit}\left(\pi_{i j k l}\right)=\beta_{0}+\beta_{1} X_{i j k l}+\left(u_{0 j k l}+v_{0 k l}+f\right.$ $\left.{ }_{01}\right)$, where $\pi_{i j k l}$ is the log odds of the outcome in child $i$, $X_{i j k l}$ is a vector of covariates, and the random effects are the residual differentials for communities $\left(u_{0 j k l}\right)$, districts $\left(v_{0 k l}\right)$, and states $\left(f_{0 l}\right)$. We then added households in order to decompose the proportion of variation in the same binary outcomes attributable to children at level one, nested in households at level two, communities at level three, districts at level four, and states at level five. For this five-level model, we estimated the probability of child $i$, in household $y$, in community $j$, in district $k$, in state $l$ experiencing the outcome $Y_{i y j k l}=1$ as equation (4) $\operatorname{logit}\left(\pi_{i y j k l}\right)=\beta_{0}+\beta_{1} X_{i j j k l}+\left(h_{y j k l}+u_{0 j k l}+v_{0 k l}+f_{0 l}\right)$. In this case, the random effects $h_{y j k l}, u_{0 j k l}, v_{0 k l}$, and $f_{0 l}$ are the residual differentials for households, communities, districts, and states, respectively. The same assumptions and parameter definitions used for equations (1) and (2) were applied to equations (3) and (4). However, the variance of the lowest levels cannot be estimated when considering binary outcomes. As such, the child-level random effect and variance is not shown. Again, we repeated the fivelevel analysis for households with more than one child.

We used the Monte Carlo Markov Chain (MCMC) method with a burn-in of 5000 cycles monitored over 50,000 chain iterations in MLwiN 3.05 software to conduct the analysis and produce the estimates for the continuous and binary outcomes in the four and five level models $[29,30]$.

\section{Results}

\section{Sample characteristics}

In the full sample of the 225,002 children with anthropometric data, the mean HAZ value was -1.48 (std. dev. 1.68). The average WAZ and WHZ values were -1.52 (std. dev. 1.22) and -0.97 (std. dev. 1.39), respectively. Approximately $38.3 \%$ of the children were stunted, $20.4 \%$ experienced wasting, and $34.5 \%$ were underweight. The average HAZ, WAZ, and WHZ values among the 128,197 children in households with more than one child were -1.59 (std. dev. 1.69), -1.60 (std. dev. 1.21), and -0.98 (std. dev. 1.37). In the restricted sample, $41.2 \%$ of children were stunted, $36.7 \%$ were underweight, and $20.4 \%$ experienced wasting. 
Of the full sample of 209,496 children with hemoglobin data, the average $\mathrm{HB}$ value was 10.6 (std. dev. 1.54). Approximately $57.5 \%$ of the children in our sample were anemic. In the restricted sample, the mean $\mathrm{HB}$ value was 10.5 (std. dev. 1.55) among the 119,668 children with complete hemoglobin data, and approximately $58.1 \%$ of the children were anemic. Finally, the average birthweight was $2.82 \mathrm{~kg}$ among the 184,852 children with birthweight data. Approximately $17.7 \%$ of the children were classified as having low birthweight. In the restricted sample, the mean birthweight was $2.81 \mathrm{~kg}$ among the 99,667 children with birthweight data, and $17.9 \%$ were classified as having low birthweight.

\section{Household level variance for continuous outcomes}

We estimated the household level variance for HAZ, WHZ, WAZ, HB, and birthweight. These results are presented in Table 1. Overall, we found that the unadjusted and adjusted household variance estimates for HAZ were
$0.47(0.01)$ and $0.41(0.01)$, respectively. For WHZ, the unadjusted and adjusted household variance estimates were $0.32(0.007)$ and $0.30(0.008)$. For WAZ, the unadjusted and adjusted household variance estimates were $0.36(0.005)$ and $0.31(0.005)$, respectively. For hemoglobin, the unadjusted household variance estimate was 0.33 (0.008), while the adjusted estimate was 0.32 (0.008). Finally, the unadjusted and adjusted household variance estimates for birthweight were $0.086(0.002)$ and 0.082 (0.002), respectively. Overall, we found that except for the child level, the largest proportion of variation was attributable to households for HAZ, WHZ, WAZ, HB, and birthweight.

\section{Household level variance for categorical outcomes}

We estimated the household level variance for stunting, wasting, underweight, anemia, and low birthweight. These results are presented in Table 2. The unadjusted and adjusted household variance estimates for stunting

Table 1 Four and five-level variance estimates (standard error) for continuous anthropometric, hemoglobin, and birthweight outcomes

\begin{tabular}{|c|c|c|c|c|c|c|c|c|}
\hline & $\begin{array}{c}4 \text { Level Unadjusted } \\
\text { HAZ } \\
\end{array}$ & $\mathbf{N}$ & $\begin{array}{c}4 \text { Level Adjusted } \\
\text { HAZ } \\
\end{array}$ & $\mathbf{N}$ & \begin{tabular}{|c}
5 Level Unadjusted \\
HAZ
\end{tabular} & $\mathbf{N}$ & $\begin{array}{c}5 \text { Level Adjusted } \\
\text { HAZ } \\
\end{array}$ & $\mathbf{N}$ \\
\hline State Variance & $0.07(0.02)$ & 36 & $0.02(0.007)$ & 36 & $0.07(0.02)$ & 36 & $0.02(0.007)$ & 36 \\
\hline District Variance & $0.05(0.004)$ & 640 & $0.03(0.003)$ & 640 & $0.05(0.004)$ & 640 & $0.03(0.003)$ & 640 \\
\hline Community Variance & $0.22(0.005)$ & 28164 & $0.18(0.005)$ & 27980 & $0.19(0.005)$ & 28164 & $0.15(0.005)$ & 27980 \\
\hline Household Variance & - & - & - & - & $0.47(0.01)$ & 164664 & $0.41(0.01)$ & 150279 \\
\hline Child Variance & $\begin{array}{c}2.39(0.008) \\
\text { 4 Level Unadjusted } \\
\text { WHZ } \\
\end{array}$ & 225002 & $\begin{array}{c}2.31(0.008) \\
\text { 4 Level Adjusted } \\
\text { WHZ } \\
\end{array}$ & 204979 & $\begin{array}{c}1.95(0.01) \\
\text { 5 Level Unadjusted } \\
\text { WHZ }\end{array}$ & 225002 & $\begin{array}{c}1.93(0.01) \\
5 \text { Level Adjusted } \\
\text { WHZ } \\
\end{array}$ & 204979 \\
\hline State Variance & $0.09(0.02)$ & 36 & $0.07(0.02)$ & 36 & $0.09(0.02)$ & 36 & $0.07(0.02)$ & 36 \\
\hline District Variance & $0.05(0.003)$ & 640 & $0.05(0.003)$ & 640 & $0.05(0.003)$ & 640 & $0.05(0.003)$ & 640 \\
\hline Community Variance & $0.14(0.003)$ & 28164 & $0.13(0.003)$ & 27980 & $0.12(0.003)$ & 28164 & $0.11(0.003)$ & 27980 \\
\hline Household Variance & - & - & - & - & $0.32(0.007)$ & 164664 & $0.30(0.008)$ & 150279 \\
\hline Child Variance & $\begin{array}{c}1.68(0.005) \\
4 \text { Level Unadjusted } \\
\text { WAZ } \\
\end{array}$ & 225002 & $\begin{array}{c}1.66(0.006) \\
\text { 4 Level Adjusted } \\
\text { WAZ } \\
\end{array}$ & 204979 & $\begin{array}{c}1.38(0.008) \\
\text { 5 Level Unadjusted } \\
\text { WAZ }\end{array}$ & 225002 & $\begin{array}{c}1.38(0.008) \\
5 \text { Level Adjusted } \\
\text { WAZ } \\
\end{array}$ & 204979 \\
\hline State Variance & $0.11(0.03)$ & 36 & $0.06(0.02)$ & 36 & $0.11(0.03)$ & 36 & $0.06(0.02)$ & 36 \\
\hline District Variance & $0.04(0.003)$ & 640 & $0.03(0.002)$ & 640 & $0.04(0.003)$ & 640 & $0.03(0.002)$ & 640 \\
\hline Community Variance & $0.11(0.002)$ & 28164 & $0.08(0.002)$ & 27980 & $0.09(0.002)$ & 28164 & $0.06(0.002)$ & 27980 \\
\hline Household Variance & - & - & - & - & $0.36(0.005)$ & 164664 & $0.31(0.005)$ & 150279 \\
\hline Child Variance & $\begin{array}{c}1.22(0.004) \\
4 \text { Level Unadjusted } \\
\text { Hemoglobin } \\
\end{array}$ & 225002 & $\begin{array}{c}1.17(0.004) \\
4 \text { Level Adjusted } \\
\text { Hemoglobin } \\
\end{array}$ & 204979 & $\begin{array}{c}0.89(0.005) \\
\begin{array}{c}5 \text { Level Unadjusted } \\
\text { Hemoglobin }\end{array} \\
\end{array}$ & 225002 & $\begin{array}{c}0.88(0.005) \\
5 \text { Level Adjusted } \\
\text { Hemoglobin }\end{array}$ & 204979 \\
\hline State Variance & $0.23(0.064)$ & 36 & $0.22(0.06)$ & 36 & $0.23(0.06)$ & 36 & $0.21(0.06)$ & 36 \\
\hline District Variance & $0.11(0.007)$ & 640 & $0.11(0.007)$ & 640 & $0.11(0.007)$ & 640 & $0.11(0.007)$ & 640 \\
\hline Community Variance & $0.19(0.004)$ & 28088 & $0.19(0.004)$ & 27878 & $0.17(0.004)$ & 28088 & $0.17(0.004)$ & 27878 \\
\hline Household Variance & - & - & - & - & $0.33(0.008)$ & 157746 & $0.32(0.008)$ & 143604 \\
\hline Child Variance & $\begin{array}{c}1.75(0.006) \\
4 \text { Level Unadjusted } \\
\text { Birthweight } \\
\end{array}$ & 209496 & $\begin{array}{c}1.72(0.006) \\
4 \text { Level Adjusted } \\
\text { Birthweight } \\
\end{array}$ & 190227 & $\begin{array}{c}1.44(0.008) \\
\begin{array}{c}5 \text { Level Unadjusted } \\
\text { Birthweight }\end{array} \\
\end{array}$ & 209496 & $\begin{array}{c}1.42(0.008) \\
5 \text { Level Adjusted } \\
\text { Birthweight }\end{array}$ & 190227 \\
\hline State Variance & $0.02(0.006)$ & 36 & $0.02(0.004)$ & 36 & $0.02(0.005)$ & 36 & $0.02(0.005)$ & 36 \\
\hline District Variance & $0.01(0)$ & 640 & $0.01(0)$ & 640 & $0.01(0)$ & 640 & $0.01(0)$ & 640 \\
\hline Community Variance & $0.02(0.001)$ & 27888 & $0.02(0.001)$ & 27619 & $0.01(0.001)$ & 27888 & $0.01(0.001)$ & 27619 \\
\hline Household Variance & - & - & - & - & $0.086(0.002)$ & 140572 & $0.082(0.002)$ & 127726 \\
\hline Child Variance & $0.32(0.001)$ & 184852 & $0.31(0.001)$ & 167838 & $0.24(0.001)$ & 184852 & $0.23(0.002)$ & 167838 \\
\hline
\end{tabular}


Table 2 Four and five-level variance estimates (standard error) for stunting, wasting, underweight, anemia, and low birthweight

\begin{tabular}{|c|c|c|c|c|c|c|c|c|}
\hline & $\begin{array}{c}4 \text { Level Unadjusted } \\
\text { Stunting } \\
\end{array}$ & $\mathbf{N}$ & $\begin{array}{c}4 \text { Level Adjusted } \\
\text { Stunting } \\
\end{array}$ & $\mathbf{N}$ & $\begin{array}{c}5 \text { Level Unadjusted } \\
\text { Stunting } \\
\end{array}$ & $\mathbf{N}$ & $\begin{array}{c}5 \text { Level Adjusted } \\
\text { Stunting } \\
\end{array}$ & $\mathbf{N}$ \\
\hline State Variance & $0.11(0.03)$ & 36 & $0.04(0.012)$ & 36 & $0.11(0.03)$ & 36 & $0.05(0.015)$ & 36 \\
\hline District Variance & $0.08(0.006)$ & 640 & $0.05(0.004)$ & 640 & $0.08(0.006)$ & 640 & $0.06(0.006)$ & 640 \\
\hline Community Variance & $0.25(0.008)$ & 28164 & $0.19(0.008)$ & 27980 & $0.22(0.007)$ & 28164 & $0.19(0.01)$ & 27980 \\
\hline Household Variance & - & - & - & - & $0.27(0.013)$ & 164664 & $0.74(0.09)$ & 150279 \\
\hline \multirow[t]{2}{*}{ Child Variance } & - & 225002 & - & 204979 & - & 225002 & - & 204979 \\
\hline & $\begin{array}{c}4 \text { Level Unadjusted } \\
\text { Wasting } \\
\end{array}$ & & $\begin{array}{c}4 \text { Level Adjusted } \\
\text { Wasting } \\
\end{array}$ & & $\begin{array}{c}5 \text { Level Unadjusted } \\
\text { Wasting } \\
\end{array}$ & & $\begin{array}{c}5 \text { Level Adjusted } \\
\text { Wasting } \\
\end{array}$ & \\
\hline State Variance & $0.17(0.05)$ & 36 & $0.14(0.04)$ & 36 & $0.21(0.06)$ & 36 & $0.18(0.05)$ & 36 \\
\hline District Variance & $0.13(0.009)$ & 640 & $0.12(0.009)$ & 640 & $0.17(0.012)$ & 640 & $0.16(0.01)$ & 640 \\
\hline Community Variance & $0.3(0.01)$ & 28164 & $0.29(0.01)$ & 27980 & $0.33(0.014)$ & 28164 & $0.31(0.01)$ & 27980 \\
\hline Household Variance & - & - & - & - & $0.89(0.04)$ & 164664 & $0.87(0.05)$ & 150279 \\
\hline \multirow[t]{2}{*}{ Child Variance } & - & 225002 & - & 204979 & - & 225002 & - & 204979 \\
\hline & $\begin{array}{c}4 \text { Level Unadjusted } \\
\text { Underweight }\end{array}$ & & $\begin{array}{l}4 \text { Level Adjusted } \\
\text { Underweight }\end{array}$ & & $\begin{array}{c}5 \text { Level Unadjusted } \\
\text { Underweight }\end{array}$ & & $\begin{array}{c}5 \text { Level Adjusted } \\
\text { Underweight } \\
\end{array}$ & \\
\hline State Variance & $0.27(0.07)$ & 36 & $0.15(0.04)$ & 36 & $0.39(0.11)$ & 36 & $0.19(0.06)$ & 36 \\
\hline District Variance & $0.09(0.007)$ & 640 & $0.07(0.005)$ & 640 & $0.14(0.01)$ & 640 & $0.09(0.01)$ & 640 \\
\hline Community Variance & $0.23(0.008)$ & 28164 & $0.17(0.008)$ & 27980 & $0.25(0.01)$ & 28164 & $0.15(0.01)$ & 27980 \\
\hline Household Variance & - & - & - & - & $1.29(0.04)$ & 164664 & $0.93(0.35)$ & 150279 \\
\hline \multirow[t]{2}{*}{ Child Variance } & - & 225002 & - & 204979 & - & 225002 & - & 204979 \\
\hline & $\begin{array}{c}4 \text { Level Unadjusted } \\
\text { Anemic } \\
\end{array}$ & $\mathbf{N}$ & $\begin{array}{c}4 \text { Level Adjusted } \\
\text { Anemic } \\
\end{array}$ & $\mathbf{N}$ & $\begin{array}{c}5 \text { Level Unadjusted } \\
\text { Anemic } \\
\end{array}$ & $\mathbf{N}$ & $\begin{array}{c}5 \text { Level Adjusted } \\
\text { Anemic } \\
\end{array}$ & $\mathbf{N}$ \\
\hline State Variance & $0.51(0.14)$ & 36 & $0.48(0.13)$ & 36 & $0.51(0.14)$ & 36 & $0.48(0.13)$ & 36 \\
\hline District Variance & $0.22(0.014)$ & 640 & $0.22(0.014)$ & 640 & $0.22(0.015)$ & 640 & $0.22(0.02)$ & 640 \\
\hline Community Variance & $0.39(0.01)$ & 28088 & $0.39(0.01)$ & 27878 & $0.39(0.01)$ & 28088 & $0.39(0.01)$ & 27878 \\
\hline Household Variance & - & - & - & - & $0(0)$ & 157746 & $0(0)$ & 143604 \\
\hline \multirow[t]{2}{*}{ Child Variance } & - & 209496 & - & 190227 & - & 209496 & - & 190227 \\
\hline & $\begin{array}{c}4 \text { Level Undjusted } \\
\text { Birthweight }(<2,500 \text { g) } \\
\end{array}$ & $\mathbf{N}$ & $\begin{array}{c}4 \text { Level Adjusted } \\
\text { Birthweight }(<2,500 \text { g) }\end{array}$ & $\mathbf{N}$ & \begin{tabular}{|c}
5 Level Und justed \\
Birthweight $(<2,500$ g) \\
\end{tabular} & $\mathbf{N}$ & $\begin{array}{c}5 \text { Level Adjusted } \\
\text { Birthweight }(<2,500 \text { g) }\end{array}$ & $\mathbf{N}$ \\
\hline State Variance & $0.19(0.06)$ & 36 & $0.19(0.06)$ & 36 & $0.26(0.08)$ & 36 & $0.21(0.06)$ & 36 \\
\hline District Variance & $0.07(0.006)$ & 640 & $0.07(0.006)$ & 640 & $0.11(0.01)$ & 640 & $0.08(0.012)$ & 640 \\
\hline Community Variance & $0.27(0.013)$ & 27888 & $0.28(0.014)$ & 27619 & $0.28(0.02)$ & 27888 & $0.27(0.019)$ & 27619 \\
\hline Household Variance & - & - & - & - & $1.49(0.24)$ & 140572 & $0.45(0.48)$ & 127726 \\
\hline Child Variance & - & 184852 & . & 167838 & - & 184852 & - & 167838 \\
\hline
\end{tabular}

were $0.27(0.013)$ and $0.74(0.09)$, respectively. For wasting, the unadjusted household variance estimate was $0.89(0.04)$, and $0.87(0.05)$ in the adjusted model. The unadjusted and adjusted household variance estimates for underweight were $1.29(0.04)$ and $0.93(0.35)$, respectively. The unadjusted and adjusted household variance estimates were both 0 (0) for anemia. Finally, for low birthweight, the unadjusted and adjusted household variance estimates were $1.49(0.24)$ and $0.45(0.48)$, respectively.

\section{Comparing four level and five level variance estimates}

We found that state and district variance estimates remained stable between the four and five-level models for each of the continuous outcomes. However, we found differences in the community variance estimates between the fully adjusted four-level and fully adjusted five-level models for all five continuous outcomes. These differences are presented in Table 3. For HAZ, the fourlevel adjusted community-level variance estimate was $17 \%$ higher than the five-level adjusted community variance estimate. For WHZ, the four-level adjusted community-level variance estimate was $15 \%$ higher than the five-level adjusted community variance estimate. For WAZ, the four-level adjusted community-level variance estimate was $25 \%$ higher than the five-level adjusted community variance estimate. For HB, the four-level adjusted community-level variance estimate was $11 \%$ higher than the five-level adjusted community variance estimate. For birthweight, the four-level adjusted community-level variance estimate was $50 \%$ higher than the five-level adjusted community variance estimate.

Similarly, we found that the adjusted four-level models overestimated the child-level variance for all five outcomes when compared to the adjusted five-level models. For HAZ, the four-level adjusted child-level variance estimate was $16 \%$ higher than the five-level adjusted community variance estimate. For WHZ, the four-level adjusted child-level variance estimate was $17 \%$ higher than the five-level adjusted community variance estimate. For WAZ, the four-level adjusted child-level variance estimate was $25 \%$ higher than the five-level adjusted community variance estimate. For HB, the four-level adjusted child-level variance estimate was $17 \%$ higher than the 
Table 3 Differences between four and five level variance estimates in adjusted models for continuous outcomes

\begin{tabular}{ccccc} 
& & 4 Level Variance & 5 Level Variance & \% Change \\
\multirow{2}{*}{ HAZ } & Community & 0.18 & 0.15 & $17 \%$ \\
& Child & 2.31 & 1.93 & $16 \%$ \\
\hline \multirow{2}{*}{ WHZ } & Community & 0.13 & 0.11 & $15 \%$ \\
& Child & 1.66 & 1.38 & $17 \%$ \\
\hline \multirow{2}{*}{ WAZ } & Community & 0.08 & 0.06 & $25 \%$ \\
& Child & 1.17 & 0.88 & $25 \%$ \\
\hline \multirow{2}{*}{ HB } & Community & 0.19 & 0.17 & $11 \%$ \\
& Child & 1.72 & 1.42 & $17 \%$ \\
\hline \multirow{2}{*}{ Birthweight } & Community & 0.02 & 0.01 & $50 \%$ \\
& Child & 0.31 & 0.23 & $26 \%$
\end{tabular}

five-level adjusted community variance estimate. Finally, for birthweight, the four-level adjusted child-level variance estimate was $26 \%$ higher than the five-level adjusted community variance estimate.

There were also differences in the variance estimates between the fully adjusted four-level and fully adjusted five-level models for the binary outcomes. For stunting, the state, district, and community variance estimates in the fully adjusted four-level model were 0.04 (0.012), 0.05 (0.004), and 0.19 (0.008), respectively, compared to 0.05 (0.015), 0.06 (0.006), and 0.19 (0.01) in the fully adjusted five-level model. For wasting, the state, district, and community variance estimates were $0.14(0.04), 0.12(0.009)$, and $0.29(0.01)$, respectively, compared to $0.18(0.05)$, $0.16(0.01)$, and $0.31(0.01)$ in the fully adjusted five-level model. For underweight, the state, district, and community variances in the fully adjusted four-level model were 0.15 (0.04), 0.07 (0.005), and 0.17 (0.008), respectively, compared to 0.19 (0.06), $0.09(0.01)$, and $0.15(0.01)$ in the fully adjusted five-level model. For low birthweight, the state, district, and community variances in the fully adjusted four-level model were 0.19 (0.06), 0.07 (0.006), and $0.28(0.014)$, respectively, compared to $0.21(0.06)$, 0.08 (0.012), and $0.27(0.019)$ in the fully adjusted fivelevel model.

\section{Households with more than one child}

We estimated the household level variance for all five continuous and binary outcomes in a subsample of the population containing homes with more than one child. These results are presented in Table 4. The unadjusted and adjusted household variance estimates for HAZ were $0.49(0.01)$ and $0.42(0.012)$, respectively. For WHZ, the unadjusted and adjusted household variance estimates were both 0.29 (0.008). For WAZ, the unadjusted and adjusted household variance estimates were 0.36 (0.006) and $0.31(0.006)$, respectively. For HB, the unadjusted household variance estimate was $0.36(0.006)$, while the adjusted estimate was $0.35(0.01)$. The unadjusted and adjusted household variance estimates for birthweight were both 0.09 (0.002).

For stunting, the unadjusted and adjusted household variance estimates were $0.88(0.03)$ and $0.76(0.04)$, respectively. The unadjusted and adjusted household variance estimates for wasting were $0.33(0.02)$ and 0.31 (0.02). For underweight, the unadjusted household variance estimate was $1.31(0.04)$ compared to $1.13(0.05)$ in the adjusted model. For anemia, the unadjusted household variance estimate was 0.017 (0.001) while the adjusted variance was 0 (0). Finally, for birthweight, the unadjusted and adjusted household variance estimates were $1.57(0.07)$ and $1.52(0.08)$, respectively. Table 5 below shows a comparison between the household-level variance estimates between the full sample and households with more than one child.

\section{Discussion}

This study had three salient findings. First, in the fourlevel models, the majority of the variance was attributable to the community and child levels. However, in the five-level models, of the four levels that children were nested in (households, communities, districts, and states), the greatest proportion of variation in child HAZ, WAZ, WHZ, HB, and birthweight was attributable to households. This was also the case for stunting, wasting, underweight, and low birthweight. It is possible this was not the case for anemia given the high prevalence of anemia in the overall sample, and because over $50 \%$ of the households with more than one child either had all children anemic or none 
Table 4 Five level variance estimates (standard error) for households with more than one child

\begin{tabular}{|c|c|c|c|c|c|c|c|c|}
\hline & $\begin{array}{c}5 \text { Level Unadjusted } \\
\text { HAZ } \\
\end{array}$ & $\mathbf{N}$ & $\begin{array}{c}5 \text { Level Adjusted } \\
\text { HAZ }\end{array}$ & $\mathbf{N}$ & $\begin{array}{c}5 \text { Level Unadjusted } \\
\text { Stunting } \\
\end{array}$ & $\mathbf{N}$ & $\begin{array}{c}5 \text { Level Adjusted } \\
\text { Stunting } \\
\end{array}$ & $\mathbf{N}$ \\
\hline State Variance & $0.063(0.018)$ & 36 & $0.02(0.007)$ & 36 & $0.15(0.04)$ & 36 & $0.05(0.02)$ & 36 \\
\hline District Variance & $0.049(0.004)$ & 640 & $0.033(0.003)$ & 640 & $0.09(0.009)$ & 640 & $0.06(0.007)$ & 640 \\
\hline Community Variance & $0.17(0.007)$ & 23936 & $0.14(0.007)$ & 23425 & $0.26(0.02)$ & 23936 & $0.20(0.02)$ & 23425 \\
\hline Household Variance & $0.49(0.01)$ & 71159 & $0.42(0.012)$ & 66320 & $0.88(0.03)$ & 71159 & $0.76(0.04)$ & 66320 \\
\hline \multirow[t]{2}{*}{ Child Variance } & $1.97(0.01)$ & 128197 & $1.94(0.012)$ & 118073 & - & 128197 & - & 118073 \\
\hline & $\begin{array}{c}5 \text { Level Unadjusted } \\
\text { WHZ }\end{array}$ & & $\begin{array}{c}5 \text { Level Adjusted } \\
\text { WHZ }\end{array}$ & & $\begin{array}{l}5 \text { Level Unadjusted } \\
\text { Wasting }\end{array}$ & $\mathbf{N}$ & $\begin{array}{c}5 \text { Level Adjusted } \\
\text { Wasting }\end{array}$ & \\
\hline State Variance & $0.089(0.03)$ & 36 & $0.073(0.02)$ & 36 & $0.20(0.06)$ & 36 & $0.17(0.05)$ & 36 \\
\hline District Variance & $0.046(0.004)$ & 640 & $0.044(0.003)$ & 640 & $0.17(0.01)$ & 640 & $0.16(0.01)$ & 640 \\
\hline Community Variance & $0.11(0.005)$ & 23936 & $0.1(0.005)$ & 23425 & $0.33(0.02)$ & 23936 & $0.31(0.02)$ & 23425 \\
\hline Household Variance & $0.29(0.008)$ & 71159 & $0.29(0.008)$ & 66320 & $0.87(0.04)$ & 71159 & $0.86(0.05)$ & 66320 \\
\hline \multirow[t]{2}{*}{ Child Variance } & $1.35(0.008)$ & 128197 & $1.35(0.008)$ & 118073 & - & 128197 & - & 118073 \\
\hline & $\begin{array}{c}5 \text { Level Unadjusted } \\
\text { WAZ }\end{array}$ & & $\begin{array}{c}5 \text { Level Adjusted } \\
\text { WAZ }\end{array}$ & & $\begin{array}{c}5 \text { Level Unadjusted } \\
\text { Underweight }\end{array}$ & $\mathbf{N}$ & $\begin{array}{l}5 \text { Level Adjusted } \\
\text { Underweight }\end{array}$ & \\
\hline State Variance & $0.1(0.03)$ & 36 & $0.057(0.016)$ & 36 & $0.40(0.11)$ & 36 & $0.23(0.06)$ & 36 \\
\hline District Variance & $0.037(0.003)$ & 640 & $0.025(0.002)$ & 640 & $0.14(0.01)$ & 640 & $0.09(0.01)$ & 640 \\
\hline Community Variance & $0.074(0.004)$ & 23936 & $0.05(0.003)$ & 23425 & $0.21(0.02)$ & 23936 & $0.14(0.02)$ & 23425 \\
\hline Household Variance & $0.36(0.006)$ & 71159 & $0.31(0.006)$ & 66320 & $1.31(0.04)$ & 71159 & $1.13(0.05)$ & 66320 \\
\hline \multirow[t]{2}{*}{ Child Variance } & $0.88(0.005)$ & 128197 & $0.87(0.005)$ & 118073 & - & 128197 & - & 118073 \\
\hline & $\begin{array}{c}5 \text { Level Unadjusted } \\
\text { Hemoglobin }\end{array}$ & & $\begin{array}{l}5 \text { Level Adjusted } \\
\text { Hemoglobin }\end{array}$ & & $\begin{array}{c}5 \text { Level Unadjusted } \\
\text { Anemic }\end{array}$ & & $\begin{array}{l}5 \text { Level Adjusted } \\
\text { Anemic }\end{array}$ & \\
\hline State Variance & $0.24(0.07)$ & 36 & $0.23(0.07)$ & 36 & $0.019(0.005)$ & 36 & $0.47(0.13)$ & 36 \\
\hline District Variance & $0.12(0.008)$ & 640 & $0.12(0.008)$ & 640 & $0.01(0.001)$ & 640 & $0.22(0.02)$ & 640 \\
\hline Community Variance & $0.16(0.006)$ & 23798 & $0.16(0.006)$ & 23277 & $0.012(0.001)$ & 23798 & $0.39(0.02)$ & 23277 \\
\hline Household Variance & $0.36(0.009)$ & 70354 & $0.35(0.01)$ & 65404 & $0.017(0.001)$ & 70354 & $0(0)$ & 65404 \\
\hline \multirow[t]{2}{*}{ Child Variance } & $1.47(0.009)$ & 119668 & $1.45(0.009)$ & 109882 & - & 119668 & - & 109882 \\
\hline & $\begin{array}{l}5 \text { Level Unadjusted } \\
\text { Birthweight (cont) }\end{array}$ & & $\begin{array}{l}5 \text { Level Adjusted } \\
\text { Birthweight (cont) }\end{array}$ & & $\begin{array}{c}5 \text { Level Unadjusted } \\
\text { Birthweight }(<2,500 \mathrm{~g})\end{array}$ & & $\begin{array}{c}5 \text { Level Adjusted } \\
\text { Birthweight }(<2,500 \mathrm{~g})\end{array}$ & \\
\hline State Variance & $0.021(0.006)$ & 36 & $0.02(0.005)$ & 36 & $0.28(0.08)$ & 36 & $0.28(0.08)$ & 36 \\
\hline District Variance & $0.01(0)$ & 640 & $0.01(0)$ & 640 & $0.11(0.01)$ & 640 & $0.11(0.01)$ & 640 \\
\hline Community Variance & $0.011(0.001)$ & 23055 & $0.01(0.001)$ & 22414 & $0.29(0.03)$ & 23055 & $0.26(0.03)$ & 22414 \\
\hline Household Variance & $0.09(0.002)$ & 57979 & $0.09(0.002)$ & 53854 & $1.57(0.07)$ & 57979 & $1.52(0.08)$ & 53854 \\
\hline Child Variance & $0.24(0.002)$ & 99667 & $0.24(0.002)$ & 91662 & - & 99667 & - & 91662 \\
\hline
\end{tabular}

Table 5 Comparison of household-level variance estimates between full sample and households with more than one child

\begin{tabular}{cccc|cccc} 
& Full Sample & $\begin{array}{c}\text { Households } \\
\text { with }>\mathbf{1} \\
\text { Child }\end{array}$ & $\begin{array}{c}\text { Percent } \\
\text { Difference }\end{array}$ & & Full Sample & $\begin{array}{c}\text { Households } \\
\text { with }>\mathbf{1} \\
\text { Child }\end{array}$ & $\begin{array}{c}\text { Percent } \\
\text { Difference }\end{array}$ \\
\cline { 2 - 6 } HAZ & 0.41 & 0.42 & $2 \%$ & Stunting & 0.74 & 0.76 & $3 \%$ \\
WHZ & 0.30 & 0.29 & $-3 \%$ & Wasting & 0.87 & 0.86 & $-1 \%$ \\
WAZ & 0.31 & 0.31 & $0 \%$ & Underweight & 0.93 & 1.13 & $18 \%$ \\
Hemoglobin & 0.32 & 0.35 & $9 \%$ & Anemic & 0 & 0 & $0 \%$ \\
Birthweight & 0.08 & 0.09 & $11 \%$ & $\begin{array}{c}\text { Birthweight } \\
(<2,500 \mathrm{~g})\end{array}$ & 0.45 & 1.52 & $70 \%$ \\
(continuous) & & & & & & &
\end{tabular}

anemic (described in supplementary Table 1). Second, we found that community and child-level variance estimates are overestimated in four-level models that omit the household level for HAZ, WAZ, WHZ, HB, and birthweight. Third, while the greatest proportion of the variation was still attributable to households in the secondary analysis, there was no substantial attenuation in the variance estimates when compared to those from the primary analysis in any of the adjusted models. However, the five-level adjusted variance estimates 
for underweight and low birthweight $(<2500 \mathrm{~g})$ were higher in the secondary analysis than in the primary analysis, possibly due to the reduced number of households in the sample.

There are four data limitations with this study. First, while NFHS data are considered extremely high quality and representative [31], it should be noted that questions about the covariates included in this study were self-reported and not verified by enumerators, a potential source of measurement error. Child anthropometric data, however, were directly measured and collected by trained field staff, and birthweight was collected using birth records. Second, there were missing observations for the outcome measures and the covariates that were included in the study. These missing observations were excluded from the study, potentially biasing the variance estimates given that the missingness might not have occurred randomly. Third, these are secondary data that were not explicitly collected for the purposes of this study. Fourth, only $5 \%$ of the households in our sample had more than one mother. As such, we were unable to disentangle the proportion of variation attributable to households versus mothers within a household. However, supplementary Table 2 shows that for HAZ, the variance estimates are very similar between 5-level and 6-level models, and 6-level models with only households with more than one mother.

Our findings are policy-relevant for several reasons. Decentralization initiated in the early 1990s has expanded the role of states and districts in designing and implementing policies. As an example, the National Nutrition Strategy, implemented by the National Institution for Transforming India, implements districtlevel interventions as a means to improving child nutrition outcomes [16]. Yet, our findings show that with the exception of HAZ and stunting, a greater proportion of variation in child malnutrition is attributable to states and communities than districts. This is confirmed by our fully adjusted four and five-level models. These findings are consistent with findings from prior studies that also show the relative importance of states and communities compared to districts when examining between-population differences in child malnutrition [11, 13, 32].

Moreover, findings from this paper underscore the importance of households as an important source of clustering and variation in child malnutrition outcomes. This has also been found previously [33], albeit in a different context, and is exemplified by the fact that of the four levels children are nested in, households accounted for the largest source of variation for all outcomes in both the unadjusted and adjusted models. This is further reflected by the fact that when the household level is omitted in the four-level models, the variance estimates at the community and child levels are overestimated by 11 to $50 \%$ and 16 to $26 \%$, respectively. The implications of this finding are that between-population differences, such as community, district, or state level contextual factors, are still important determinants of child health. Yet the environments within those geographic levels that people are embedded in, such as households, also function as sources of variation in child malnutrition. This is a particularly important implication given the heterogeneity of child malnutrition outcomes within geographic levels [32]. Therefore, our findings signal the importance of designing policies and interventions that account for the most vulnerable individuals and households within a population in addition to addressing contextual factors at the state and community levels aimed at lowering mean rates of child malnutrition between populations [1720]. Doing so could help alleviate between and within population disparities in child malnutrition throughout India.

That our findings highlight households as a significant source of variation in child malnutrition outcomes should not undermine efforts aimed at addressing the upstream and social determinants of child malnutrition. This is an important point given that the utility of multilevel modeling is to draw attention away from individuals and households in order to examine placebased effects on health [26-28]. However, underscoring households as important sites of clustering is not at odds with a social epidemiological approach to improving child malnutrition outcomes. This is highlighted by a growing body of literature which demonstrates the relative importance of upstream factors within households when compared to individual-level factors in determining child malnutrition. For example, recent studies show the relative importance of household socioeconomic status and maternal characteristics over nutrition-specific risk factors, such as child feeding practices [5, 24, 25, 34, 35]. Previous work also suggests that investing in early nutrition for girls at the household level is important given that maternal height is strongly associated with child height in the subsequent generation $[7,23,36]$. To this end, a recent study found that children born to mothers who received consistent meals in school had significantly higher HAZ scores than children born to mothers who did not receive this benefit [37]. Another recent study from Odisha shows that providing conditional cash transfers to mothers in poor households can also lead to significant reductions in stunting and anemia among children under five [38]. Evidence suggests that cash transfers can empower women who then invest in the health and wellbeing of their children $[8,24,39]$. Future research should 
examine the associations between other housing environmental conditions, such as sanitation, clean cooking fuel, and refrigeration, all of which are associated with faltering child growth outcomes [40-42].

\section{Conclusion}

The purpose of this paper was to examine the proportion of variation in child stunting, wasting, underweight, anemia, and low birthweight attributable to the household level relative to commonly analyzed levels such as communities, districts, and states. Overall, we found that of the four levels that children were nested in (households, communities, districts, and states), the greatest proportion of variation in child HAZ, WAZ, WHZ, hemoglobin, birthweight, stunting, underweight, wasting, anemia, and low birthweight was attributable to households. Furthermore, we found that when the household level is omitted from models, the variance estimates for communities and children are overestimated. This implies that households are an important lower-level responsible for a considerable proportion of the variation in child malnutrition.

\section{Supplementary Information}

The online version contains supplementary material available at https://doi. org/10.1186/s12939-021-01563-7.

Additional file 1: Supplementary Table 1: Prevalence of anemia among children in households with more than one child.

Additional file 2: Supplementary Table 2: Comparison of variance estimates for HAZ between 5-level and 6-level models, and 6-level models with only households with more than one mother.

\section{Acknowledgments}

The authors would like to thank the Demographic and Health Surveys program for making the fourth National Family Health Survey data freely accessible.

\section{Authors' contributions}

Conceptualization and Design: SVS, AJ, JR, RK. Data Acquisition and Analysis: AJ. Data Interpretation: AJ, SVS, JR, RK. Drafting of the Manuscript: AJ. Critical revisions to Manuscript: SVS, JR, RK. Overall Supervision: SVS. All authors read and approved the final manuscript.

\section{Funding}

This research was funded by Bill \& Melinda Gates Foundation, INV-002992.

\section{Availability of data and materials}

The data that support the findings of this study are openly available in India: Standard DHS, 2015-2016 Dataset at https://dhsprogram.com/data/dataset/ India_Standard-DHS_2015.cfm?flag $=0$.

\section{Declarations}

\section{Ethics approval}

NA

\section{Consent for publication}

NA

\section{Competing interests}

The authors have no competing interests to disclose.

\section{Author details}

${ }^{1}$ Global Health \& Social Medicine, Harvard Medical School, Boston, MA 02115 , USA. ${ }^{2}$ Harvard Center for Population and Development Studies, Cambridge, MA 02138, USA. ${ }^{3}$ Division of Health Policy \& Management, College of Health Science, Korea University, Seoul 02841, South Korea. ${ }^{4}$ Interdisciplinary Program in Precision Public Health, Department of Public Health Sciences, Graduate School of Korea University, Seoul 02841, South Korea. ${ }^{5}$ Harvard Center for Population and Development Studies, MA 02138 Cambridge, USA. ${ }^{6}$ Department of Social and Behavioral Sciences, Harvard T.H. Chan School of Public Health, Boston, MA 02115, USA.

Received: 1 April 2021 Accepted: 28 September 2021

Published online: 12 October 2021

\section{References}

1. 2018 Global Nutrition Report [Internet]. [cited 2021 Jan 31]. Available from: https://globalnutritionreport.org/reports/global-nutri tion-report-2018/.

2. Swaminathan S, Hemalatha R, Pandey A, Kassebaum NJ, Laxmaiah A, Longvah $T$, et al. The burden of child and maternal malnutrition and trends in its indicators in the states of India: the global burden of disease study 1990-2017. Lancet Child Adolesc Health. 2019;3(12):855-70.

3. Black RE, Morris SS, Bryce J. Where and why are 10 million children dying every year? Lancet. 2003;361(9376):2226-34

4. Grantham-McGregor S, Cheung YB, Cueto S, Glewwe P, Richter L, Strupp B. Developmental potential in the first 5 years for children in developing countries. Lancet. 2007;369(9555):60-70.

5. Corsi DJ, Mejía-Guevara I, Subramanian SV. Risk factors for chronic undernutrition among children in India: estimating relative importance, population attributable risk and fractions. Soc Sci Med. 2016;157:165-85.

6. Martorell R, Young MF. Patterns of stunting and wasting: potential explanatory factors. Adv Nutr. 2012;3(2):227-33.

7. Kim R, Rajpal S, Joe W, Corsi DJ, Sankar R, Kumar A, et al. Assessing associational strength of 23 correlates of child anthropometric failure: an econometric analysis of the 2015-2016 National Family Health Survey, India. Soc Sci Med. 2019;238:112374.

8. Menon P, Headey D, Avula R, Nguyen PH. Understanding the geographical burden of stunting in India: a regression-decomposition analysis of district-level data from 2015-16. Matern Child Nutr. 2018;14(4):e12620.

9. Cavatorta E, Shankar B, Flores-Martinez A. Explaining cross-state disparities in child nutrition in rural India. World Dev. 2015:76:216-37.

10. Ackerson LK, Kawachi I, Barbeau EM, Subramanian SV. Geography of underweight and overweight among women in India: a multilevel analysis of 3204 neighborhoods in 26 states. Econ Hum Biol. 2008;6(2):264-80.

11. Mejía-Guevara I, Krishna A, Corsi DJ, Subramanian SV. Individual and ecological variation in child undernutrition in India: a multilevel analysis. J South Asian Dev. 2015;10(2):168-98.

12. Balarajan $Y$, Selvaraj S, Subramanian S. Health care and equity in India. Lancet. 2011;377(9764):505-15.

13. Mohanty SK, Kim R, Khan PK, Subramanian SV. Geographic variation in household and catastrophic health spending in India: assessing the relative importance of villages, districts, and states, 2011-2012: geographies of household and catastrophic health spending in India. Milbank Q. 2018;96(1):167-206.

14. Rodgers J, Kim R, Subramanian SV. Explaining Within- vs BetweenPopulation Variation in Child Anthropometry and Hemoglobin Measures in India: A Multilevel Analysis of the National Family Health Survey 2015-2016. J Epidemiol [Internet]. 2019 [cited 2020 May 15]; Available from: https://www.jstage.jst.go.jp/article/jea/advpub/0/advpub_JE201 90064/_article.

15. Galobardes B. Indicators of socioeconomic position (part 1). J Epidemiol Community Health. 2006;60(1):7-12.

16. Kumar A, Kaur S, Singh A, Menon P. Accelerating progress on nutrition in India: What Will It Take? 2020. https://www.niti.gov.in/sites/default/files/ 2020-10/AbhiyaanMonitoringReport.pdf. 
17. Rose G. Sick individuals and sick populations. Int J Epidemiol. 2001;30(3):427-32.

18. Mejía-Guevara I, Corsi DJ, Perkins JM, Kim R, Subramanian SV. Variation in anthropometric status and growth failure in low- and middle-income countries. Pediatrics. 2018;141(3):e20172183.

19. Subramanian SV, Kim R, Christakis NA. The "average" treatment effect: a construct ripe for retirement. A commentary on Deaton and cartwright. Soc Sci Med. 2018;210:77-82.

20. Subramanian SV, Mejía-Guevara I, Krishna A. Rethinking policy perspectives on childhood stunting: time to formulate a structural and multifactorial strategy: rethinking policy perspectives on stunting. Matern Child Nutr. 2016;12:219-36.

21. Subramanian SV, Kim R. Sick countries and sick individuals: reassessing the inferential targets in global health research. Lancet Glob Health. 2018;6(7):e726-7.

22. International Institute for Population Sciences (IIPS) and ICF. National Family Health Survey (NFHS-4), 2015-16. Mumbai: IIPS; 2017.

23. Subramanian SV. Association of maternal height with child mortality, anthropometric failure, and Anemia in India. JAMA. 2009;301(16):1691.

24. Bhutta ZA, Ahmed T, Black RE, Cousens S, Dewey K, Giugliani E, et al. What works? Interventions for maternal and child undernutrition and survival. Lancet. 2008;371(9610):417-40.

25. Ruel MT, Alderman $\mathrm{H}$. Nutrition-sensitive interventions and programmes: how can they help to accelerate progress in improving maternal and child nutrition? Lancet. 2013;382(9891):536-51.

26. Krieger N. A glossary for social epidemiology. J Epidemiol Community Health. 2001;55(10):693-700.

27. Diez-Roux AV. Bringing context back into epidemiology: variables and fallacies in multilevel analysis. Am J Public Health. 1998;88(2):216-22.

28. Berkman LF, Kawachi I, editors. Social epidemiology. New York: Oxford University Press; 2000. $391 \mathrm{p}$

29. Browne WJ. MCMC estimation in MLwiN v3.03: University of Bristol: Centre for Multilevel Modelling; 2019.

30. Charlton C, Rabash J, Browne WJ, Healy M, Cameron B. MLwiN Version 3.05: University of Bristol: Centre for Multilevel Modelling; 2020.

31. Corsi DJ, Neuman M, Finlay JE, Subramanian SV. Demographic and health surveys: a profile. Int J Epidemiol. 2012;41(6):1602-13.

32. Rajpal S, Kim J, Joe W, Kim R, Subramanian SV. Small area variation in child undernutrition across 640 districts and 543 parliamentary constituencies in India. Sci Rep. 2021;11(1):4558.
33. Vaezghasemi M, Ng N, Eriksson M, Subramanian SV. Households, the omitted level in contextual analysis: disentangling the relative influence of households and districts on the variation of BMI about two decades in Indonesia. Int J Equity Health. 2016;15(1):102.

34. Black RE, Allen LH, Bhutta ZA, Caulfield LE, de Onis M, Ezzati M, et al. Maternal and child undernutrition: global and regional exposures and health consequences. Lancet. 2008;371(9608):243-60.

35. Kim R, Mejía-Guevara I, Corsi DJ, Aguayo VM, Subramanian SV. Relative importance of 13 correlates of child stunting in South Asia: insights from nationally representative data from Afghanistan, Bangladesh, India, Nepal, and Pakistan. Soc Sci Med. 2017;187:144-54.

36. Perkins JM, Subramanian SV, Davey Smith G, Özaltin E. Adult height, nutrition, and population health. Nutr Rev. 2016;74(3):149-65.

37. Chakrabarti S, Scott SP, Alderman H, Menon P, Gilligan DO. Intergenerational nutrition benefits of India's national school feeding program. Nat Commun. 2021;12(1):4248.

38. Chakrabarti S, Pan A, Singh P. Maternal and child health benefits of the Mamata conditional cash transfer program in Odisha, India. J Nutri. 2021;151(8):2271-81. https://doi.org/10.1093/jn/nxab129.

39. Branca F, Piwoz E, Schultink W, Sullivan LM. Nutrition and health in women, children, and adolescent girls. BMJ. 2015;14:h4173.

40. Prüss-Üstün A, Bos R, Gore F, Bartram J, World Health Organization. Safe water, better health: costs, benefits and sustainability of interventions to protect and promote health [Internet]. 2008 [cited 2021 Jan 25]. Available from: http://whqlibdoc.who.int/publications/2008/9789241596435_eng. pdf

41. Fink G, Günther I, Hill K. The effect of water and sanitation on child health: evidence from the demographic and health surveys 1986-2007. Int J Epidemiol. 2011;40(5):1196-204.

42. Karlsson O, Kim R, Joe W, Subramanian SV. The relationship of household assets and amenities with child health outcomes: an exploratory crosssectional study in India 2015-2016. SSM - Popul Health. 2020;10:100513.

\section{Publisher's Note}

Springer Nature remains neutral with regard to jurisdictional claims in published maps and institutional affiliations.
Ready to submit your research? Choose BMC and benefit from:

- fast, convenient online submission

- thorough peer review by experienced researchers in your field

- rapid publication on acceptance

- support for research data, including large and complex data types

- gold Open Access which fosters wider collaboration and increased citations

- maximum visibility for your research: over $100 \mathrm{M}$ website views per year

At BMC, research is always in progress.

Learn more biomedcentral.com/submissions 